\title{
PEMETAAN KONFLIK ANTARA PERUSAHAAN PERKEBUNAN DENGAN MASYARAKAT SEKITAR
}

\section{Lucyana Trimo}

Program Studi Agribisnis Departemen Sosial Ekonomi Pertanian Fakultas Pertanian UNPAD E-mail: lucyana.trimo@unpad.ac.id

\begin{abstract}
ABSTRAK
Pemetaan konflik dapat mengklarifikasi berbagai level permasalahan, memberikan gambaran menyeluruh, mengorganisasi titik pandang setiap orang dan memberi solusi efektif. Penelitian ini bertujuan memetakan pemicu konflik, jenis konflik, dan penanganan konflik oleh perusahaan. Penelitian dilakukan di Perkebunan Tambaksari PTPN VIII Subang dengan desain kualitatif dan metode studi kasus. Staf perkebunan, tokoh masyarakat, LSM, staf desa, staf kecamatan, karyawan perkebunan dan masyarakat di sekitar perkebunan dipilih secara sengaja sebagai informan dengan menggunakan teknik snowball sampling. Data yang diperoleh dianalisis dengan menggunakan pendekatan triangulasi. Hasil pemetaan mengungkap bahwa konflik dipicu oleh kondisi masyarakat sekitar yang miskin, kondisi perusahaan yang melemah, provokasi pihak ketiga dan tidak adanya ganti rugi atas lahan garapan masyarakat yang sekarang dikonversi menjadi kelapa sawit oleh perusahaan. Konflik berwujud penyerobotan lahan perusahaan. Penanganan konflik sudah berlangsung lama dan melibatkan berbagai pihak terkait, namun semua pihak belum memahami pentingnya melakukan pemetaan konflik. Perlu integrasi atau kolaborasi pendekatan formal dan lokal dalam pemetaan konflik agraria.
\end{abstract}

Kata kunci: pemetaan konflik, perusahaan perkebunan, masyarakat sekitar

\begin{abstract}
Mapping the conflict may clarify the various levels of problems, giving a whole, organizing point of view of each person and provide effective solutions. This study aims to map a trigger of conflict, types of conflicts, and conflict management by the company. The study was conducted in Plantation PTPN VIII Tambaksari Subang with qualitative design and the case study method. Plantation staff, community leaders, NGOs, village staff, district staff, plantations employees and communities around the plantation been deliberately as an informant by using snowball sampling technique. Data were analyzed using triangulation approach. Mapping results reveal that the conflict was triggered by the poor condition of the surrounding communities, business conditions weakened, provocation third parties and the absence of compensation for people whose arable land is now converted into oil palm by the company. Conflict tangible land grabbing companies. Handling conflict has lasted a long time and involve multiple stakeholders, but all parties do not understand the importance of mapping the conflict. Need integration formal and local approaches to mapping agrarian conflicts.
\end{abstract}

Keywords: conflict mapping, plantation companies, local communities

\section{PENDAHULUAN}

Secara hostoris, konflik perkebunan di Indonesia sudah berjalan cukup lama dan fenomenanya meningkat pasca reformasi tahun 1997. Badan Pertanahan Nasional (2002) mencatat, pada tahun 2000 terdapat sekitar 236 kasus konflik sosial masyarakat di sentra-sentra perkebunan di 15 provinsi di Indonesia, termasuk Jawa Barat. Kasus yang paling banyak mengemuka adalah pengambilalihan lahan dan penjarahan hasil perkebunan yang merugikan hingga nilai miliaran rupiah.
Dipandang dari aspek menajemen perusahaan perkebunan, sebenarnya masyarakat sekitar lokasi perusahaan perkebunan dapat dianggap sebagai asset sumber daya manusia (SDM) perusahaan, yang dapat mendukung perkembangan dan pengembangan perusahaan perkebunan. Namun demikian, karena masyarakat sekitar perkebunan merupakan pihak yang relatif sulit untuk dikendalikan (uncontrollable) oleh perusahaan, maka masyarakat bisa menjadi gangguan operasional, terutama keamanan. 
Saat ini masyarakat semakin menyadari bahwa perusahaan telah menggali kekayaan alamnya, namun mereka kurang mendapat perhatian yang layak bahkan lingkungan sekitarnya terganggu dengan hadirnya Perusahaan Perkebunan, sehingga menuntutnya berkontribusi bagi kesejahteraan hidup mereka. Secara riil, konflik lebih banyak terjadi di perkebunan daripada di lahan hortikultura dan pangan, karena perkebunan memerlukan lahan luas, dikuasai pihak tertentu dan sedikit memperkerjakan masyarakat sekitar. Sedangkan usaha hortikultura dan pangan tersebar kepemilikannya, penggarapannya dibagi-bagi dengan masyarakat sekitar dan banyak memperkerjakan masyarakat sekitar.

Konflik perkebunan dengan masyarakat dapat terjadi karena adanya perbedaan pandangan, kebutuhan, komunikasi, tujuan, kepentingan dan issue yang berkembang. Konflik sendiri didefinisikan sebagai pertentangan atau perselisihan akibat adanya perbedaan dan kesenjangan. Konflik dapat terjadi antar individu dalam suatu perusahaan, antar perusahaan, maupun perusahaan dengan masyarakat di sekitarnya. Konflik yang terjadi di dalam (internal) perusahaan atau antar perusahaan lebih mudah untuk ditangani, sedangkan konflik antar perusahaan dengan masyarakat sekitar lebih sulit ditangani.

Perusahaan yang berkembang di tengah masyarakat lebih berpotensi mengalami pergesekan. Ini terjadi jika keberadaan perusahaan tidak dirasakan manfaatnya oleh masyarakat sekitar. Kondisi tersebut memudahkan timbulnya konflik bagi kedua belah pihak. Pemahaman tentang substansi konflik yang sedang terjadi, memudahkan seseorang untuk menyelesaikan konflik tersebut. Selain itu, konflik yang tidak diupayakan pemecahannya secara dini, cenderung akan terus membesar. Agar konflik dapat ditangani secara efektif dan efisien, maka diperlukan pengenalan dan pemetaan akar konflik. Penelitian ini bertujuan memetakan antar perusahaan perkebunan dengan masyarakat sekitar.

\section{KERANGKA TEORITIS}

Konflik timbul dari ketidakseimbangan dalam status sosial, kekayaan dan akses terhadap sumber-sumber serta ketidakseimbangan dalam kekuasaan yang mengakibatkan munculnya berbagai problematika (seperti: diskriminasi, pengangguran, kemiskinan, penindasan dan kriminalitas) (Mukhsin Jamil, 2007). Ada banyak sumber penyebab konflik, salah satunya adalah faktor komunikasi yang oleh sebagian pakar sering disebut sumber konflik utama. Mohammad A. Ghani (2003) menyatakan bahwa, dalam perspektif manajemen modern, stakholders perusahaan bukan terbatas pemilik dan pekerja saja, melainkan juga pemerintah daerah, masyarakat sekitar, dan pihak-pihak yang langsung maupun tidak langsung dapat mempengaruhi jalannya perusahaan.

Masyarakat sekitar dapat digolongkan stakholders karena sebagai pihak yang bertetangga, sering memiliki kepentingan yang sama atau bahkan bisa bersinggungan dengan perusahaan, yang implikasinya bisa mempengaruhi aktivitas perkebunan. Kantongkantong kemiskinan di sekitar kebun akan memicu tumbuhnya kecemburuan. Pada akhirnya, mudah disusupi pihak ketiga untuk mengganggu, baik langsung berupa pencurian produk dan aset atau perilaku kurang bersahabat terhadap pemanfaatan sumberdaya yang sama seperti air, akses jalan, ataupun tidak langsung.

Selain itu, konflik yang bersumber dari reclaiming masyarakat sekitar atas lahan terlantar yang selama ini digarapnya juga muncul sebagai akibat dari penerapan program peningkatan mutu perkebunan pada tahun 1980an yang didesakan pemerintah agar perusahaan perkebunan menggarap lahan-lahan yang selama ini ditelantarkan. Sumber konflik lainnya adalah masa Hak Guna Usaha (HGU) perusahaan perkebunan yang habis atau sedang menunggu untuk diperbaharui, yang dapat memberi peluang bagi sebagian masyarakat sekitar perkebunan untuk melakukan penjarahan.

Undang Fajar (2006) menyatakan bahwa, berbagai sumber konflikpun muncul dalam pola kemitraan usaha antara perusahaan perkebunan dan masyarakat. Hal tersebut terjadi karena pada hakekatnya sejumlah ketidakharmonisan, ketidakselarasan, dan ketimpangan atau incompatibilitas. Dinyatakan pula, paling tidak terdapat tiga macam incompabilitas, yaitu: (1) ketimpangan dalam struktur kepemilikan asset, (2) ketimpangan dalam hal persepsi dan konsepsi, dan (3) ketimpangan antara apa yang dikatakan dengan apa yang dilakukan.

Alat atau teknik untuk membantu dalam mengidentifikasi, akar permasalahan, menganalisa, dan memecahkan konflik adalah 
dengan menggunakan pemetaan konflik. Mengapa pemetaan konflik dianggap penting? Karena konflik tidak muncul tiba-tiba tanpa sebab, dan banyak faktor yang mempengaruhinya seperti misalnya hubungan, nilai-nilai yang ada dalam suatu masyarakat, kelembagaan, kebutuhan individu/kelompok, perkembangan sebuah komunitas, sumber daya, kebijakan dan kepentingan politik tertentu. Dengan melalui pemetaan konflik, maka dapat merepresentasikan konflik dalam bentuk visualisasi baik berupa gambar dalam bentuk bagan, diagram, grafis, dan lain-lain, dengan menempatkan para pihak yang terlibat dalam konflik baik yang berhubungan dengan masalah maupun antar para pihak sendiri.

Melalui metode pemetaan, dapat memberikan sebuah sistem yang menggambarkan scope dari suatu konflik dengan tujuan dari pihak yang terlibat di dalamnya, tipe hubungannya, dan juga isi dari isunya. Mengidentifikasi pihak yang terlibat konflik merupakan tahap yang pertama kali dilakukan untuk mengetahui posisi mereka, kepentingan, dan tingkat kapasitas dari dukungan dari luar. Oleh karena itu, kerangka kerja dari analisis konflik harus bersifat komprehensif, yaitu dengan memperhatikan berbagai aspek yang melingkupinyanya, seperti apa yang diungkapkan oleh Bartos and Wehr (2002).

"The analysis of linkages between microlevel activities and macro-level forces covers the main obstacles working against a peaceful solution and the internal and external factors behind prolonging the conflict. Overall, mapping entails essential information that is fundamental in planning a constructive response, including the control of violence."

Suatu hal yang penting dari pemetaan konflik adalah membantu pihak yang terlibat konflik untuk melihat dengan jelas posisi mereka terhadap kepentingan dan kebutuhan mereka, saat mengklarifikasi berbagai macam permasalahan. Ini sesuai pula dengan konsep pemetaan konflik dari Fisher dkk. (2000), yang menggambarkan siapa saja yang terlibat konflik, kepentingan dari pihak-pihak yang terlibat konflik (misalnya perusahaan perkebunan dan masyarakat sekitar), tujuan yang diinginkan oleh masing-masing pihak yang berkonflik, serta penanganan konflik yang telah diterapkan oleh pihak perusahaan.
Selanjutnya terdapat satu pertanyaan penting, yaitu kapan pemetaan konflik digunakan? De Boers dan Hoa Pham (2009) menyatakan bahwa: a) pemetaan dapat digunakan pada peristiwa apa saja ketika kita membutuhkan klarifikasi suatu permasalahan, b) pemetaan dapat digunakan untuk suatu situasi yang sifatnya sederhana maupun yang kompleks, c) pemetaan dapat digunakan secara individu maupun kelompok kecil atau besar, d) menggunakan pemetaan untuk membantu dalam perencanaan, e) mempertimbangkan kebutuhan dan perhatian sebelum membuat rencana baru atau merubah implementasi untuk menghindari banyak tekanan dan konflik, itu akan membangun hubungan yang terbaik, f) memetakan suatu isu dapat menyediakan suatu proses terstruktur yang berhubungan dengan isu yang bersifat kooperatif, dan g) ketika isu terlihat sangat kompleks, atau ketika melibatkan pemikiran yang lemah untuk memecahkannya, pemetaan dapat menjadi suatu titik awal yang sangat baik. Melihat gambaran yang menyeluruh dan mengorganisasi titik pandang setiap orang seringkali menyebabkan seseorang memiliki kemampuan untuk mengidentifikasi pihak-pihak yang dapat bekerjasama.

\section{METODE PENELITIAN}

Metode yang digunakan dalam penelitian ini adalah kualitatif. Metode kualitatif adalah, penelitian yang tempat dan waktunya bersifat alamiah, peneliti merupakan instrument penelitian, dan kemudian data yang diperoleh dianalisis secara induktif lalu proses yang diteliti dijelaskan secara ekspresif, bersifat eksploratif dan peneliti menggunakan penelitian tersebut untuk mengupas sebuah topik ketika variable dan dasar teorinya tidak diketahui (Creswell, 1998).

Metode penelitian kualitatif berfokus pada persepsi dan pengalaman serta cara memandang suatu kehidupan dan peneliti terutama tertarik untuk memahami bagaimana suatu hal terjadi (Fraenkel dan Walen, 1990; Merriam, 1988; serta Locke dkk.1987 dalam Creswell, 1998). Pendekatan penelitian ini adalah studi kasus. Disain dari studi kasus ini lebih memberikan kemungkinan kepada peneliti untuk memperoleh wawasan yang mendalam mengenai aspek-aspek dasar tentang perilaku manusia. Hal ini disebabkan karena studi kasus berupaya melakukan penyelidikan secara mendalam dan totalitas, intensif dan utuh (Muhamad Idrus, 2007). 
Data yang dikumpulkan dalam penelitian ini terdiri dari data primer dan data sekunder. Data primer diperoleh dari pengamatan secara langsung di lapangan, dan melakukan wawancara dengan berpedoman pada kuesioner yang telah dipersiapkan terlebih dahulu. Wawancara (interview) dilakukan terhadap informan: administratur, staf administratur dan karyawan yang bekerja di Perkebunan Teh Tambaksari PTPN VIII Subang, serta masyarakat yang tinggal di sekitar perkebunan tersebut (masyarakat yang bekerja di perusahaan perkebunan dan bukan pekerja di perkebunan yang tinggal di sekitar perkebunan), tokoh masyarakat, aparat desa (Kepala Desa dan staf), aparat Kecamatan (Camat dan staf), LSM (Lembaga Swadaya Masyarakat), dan staf BPD (Badan Pembangunan Desa) yang ditentukan secara sengaja dan ditentukan dengan menggunakan teknik snowball sampling. Data sekunder dipeoleh dari studi dokumentasi dan literatur, melalui cara mengumpulkan dan mempelajari data tertulis berupa buku-buku, dokumen-dokumen atau transkip, koran, jurnal, buletin, dan membuka akses melalui internet.

\section{HASIL DAN PEMBAHASAN}

Pemetaan konflik dipakai untuk merepresentasikan konflik dalam bentuk visualisasi gambar (grafis) maupun bagan, dengan menempatkan para pihak yang terlibat dalam konflik maupun pihak yang menjadi mediator, serta waktu kejadiannya.

Berdasarkan hasil pemetaan diperoleh bahwa konflik antara perusahaan perkebunan dengan masyarakat sekitar dipicu karena kondisi perusahan perkebunan dan masyarakat kurang memperhatikan keinginan masing-masing pihak. Perusahaan perkebunan berkeinginan agar perusahaannya tetap memiliki kinerja yang tetap tinggi dan eksistensinya diakui oleh masyarakat sekitar. Masyarakat sekitar ingin sejahtera dan merasakan bahwa perusahaan perkebunan yang ada di wilayahnya dapat memberikan manfaat bagi kesejahteraannya.

Dari pihak perusahaan perkebunan sendiri konflik dipicu oleh pengelolaan lahan perkebunan yang tidak optimal, kurangnya penyerapan tenaga kerja dari masyarakat sekitar, dan kurang tepatnya implementasi program kepeduliaan kepada masyarakat oleh perusahan perkebunan, serta didukung oleh lamanya proses pepanjangan HGU. Dari pihak masyarakat konflik dipicu oleh kesejahteraan masyarakat sekitar perusahaan yang masih rendah, karena adanya keterbatasan lahan petanian, terbatasnya pengetahuan dan kererampilan, dan terbatasnyalapngan pekrejaan. Adanya kedua kondisi tersebut, mengakibatkan terjadinya penyerobotan lahan tidur milik perusahaan perkebunan oleh masyarakat sekitar (Gambar 1).

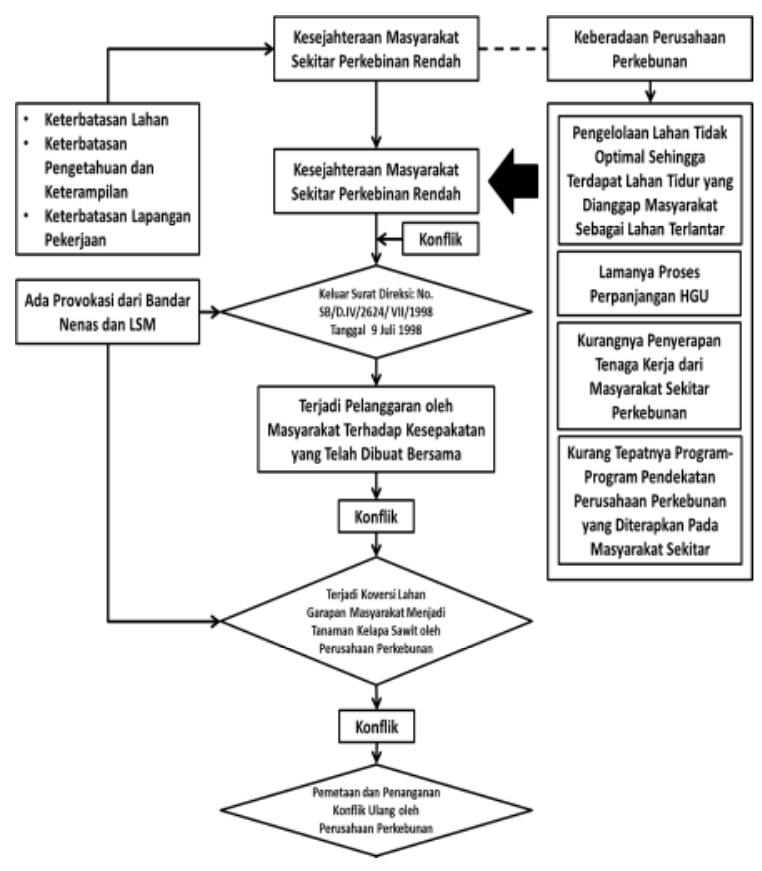

Gambar 1. Pemetaan Pemicu Konflik Perusahaan Perkebunan dengan Masyarakat Sekitar

Penyerobotan lahan tesebut kemudian semakin terpicu dengan adanya provokasi dari orang-orang yang ingin memanfaatkan situasi dari kurangnya perhatian perusahaan terhadap masyarakat sekitar. Akibatnya masyarakat sekitar perusahaan perkebunan (sebagai penggarap) semakin berani untuk menggarap lahan perusahaan perkebunan, sehingga penyerobotan lahan perusahaan tidak saja teradi pada lahan tidur, namun juga pada lahan produktif, terlebih lagi perusahaan tidak melakukan monitoring penggarapan lahan secara ketat.

Pada Gambar 1 tersebut, terlihat pula bahwa konflik masih selalu terjadi. Dinamika konflik tersebut dapat terjadi antara lain karena surat perjanjian yang berisi kesepakatan bersama antara kedua belah pihak selalu dilanggar oleh penggarap. Selain itu, kurangnya komunikasi antara kedua belah pihak dalam menginformasikan surat perjanjian dan rencana-rencana yang akan dilakukan oleh pihak perusahaan perkebunan, dan pada 
Tabel 1. Jumlah Penggarap dan Luas Areal yang Digarap Masyarakat

\begin{tabular}{|c|c|c|c|c|c|c|c|}
\hline \multirow[b]{2}{*}{ Afdeling } & \multirow{2}{*}{$\begin{array}{l}\text { Jumlah } \\
\text { penggarap } \\
\text { (orang) }\end{array}$} & \multirow{2}{*}{$\begin{array}{l}\text { Luas } \\
\text { garapan } \\
(\mathrm{Ha})\end{array}$} & \multirow{2}{*}{$\begin{array}{l}\text { Mulai } \\
\text { digarap } \\
\text { (tgl/bl/th) }\end{array}$} & \multirow{2}{*}{$\begin{array}{l}\text { Jenis } \\
\text { tanaman }\end{array}$} & \multicolumn{2}{|c|}{ Surat perjanjian } & \multirow{2}{*}{$\begin{array}{l}\text { Rencana } \\
\text { Tahun } 2007\end{array}$} \\
\hline & & & & & $\begin{array}{l}\text { Pihak } \\
\text { kesatu }\end{array}$ & $\begin{array}{l}\text { Pihak } \\
\text { kedua }\end{array}$ & \\
\hline Palasari & 492 & 44,63 & $14 / 10 / 1998$ & Nenas & Adm. & Penggarap & - \\
\hline Tambaksari & 618 & 95,05 & 14/10/1998 & Nenas & Adm. & Penggarap & TTI-S \\
\hline Kasomalang & 254 & 41,38 & 14/10/1998 & Nenas & Adm. & Penggarap & TTI-S \\
\hline Bukanagara & 207 & 14,92 & 14/10/1998 & Sayuran & Adm. & Penggarap & - \\
\hline Sindangsari & 719 & 256,68 & 14/10/1998 & Nenas & Adm. & Penggarap & TTI-S \\
\hline Sarireja & 540 & 81,35 & 14/10/1998 & Nenas & Adm. & Penggarap & - \\
\hline PLTA & 15 & 2,24 & $14 / 10 / 1998$ & Padi & Adm. & Penggarap & - \\
\hline Jumlah & 2.845 & 536,245 & & & & & \\
\hline
\end{tabular}

Keterangan: Adm. $=$ Administratur

Sumber:Perkebunan Tambaksari PTP Nusantara VIII, 2011.

akhirnya dapat menimbulkan konflik baru. Munculnya konflik baru ini juga didukung oleh model penanganan konflik yang diterapkan oleh pihak perusahaan yang masih bersifat instan dan tidak berkelanjutan.

Konflik antara Perkebunan Tambaksari PTPN VIII dengan masyarakat sekitar masih terus berlanjut karena proses pengurusan perpanjangan HGU (Hak Guna Usaha) masih belum selesai, penjarahan lahan tidur milik perkebunan oleh masyarakat untuk penanaman nenas semakin luas, dan terjadi konversi dari lahan tidur milik Perkebunan Tambaksari yang ditanami nenas oleh masyarakat menjadi tanaman kelapa sawit oleh Perkebunan Tambaksari tanpa ganti rugi.

Areal lahan yang digarap oleh masyarakat sekitar perkebunan dan karyawan perkebunan, adalah seluas 536,245 ha (17,33 persen dari luas total Perkebunan Tambaksari yaitu 2.529,395 ha atau 21,20 persen dari areal tanaman teh). Sebagian besar dari lahan tersebut, sudah direncanakan bahwa pada tahun 2007 akan ditanami Tanaman Takeling Industri-Sawit (TTIS). Rincian lahan yang diizinkan digarap oleh masyarakat sekitar dapat dilihat pada Tabel 1 .

Penanaman lahan garapan dengan tanaman nenas, telah melanggar aturan Direksi PTPN VIII (Surat Direksi No.

SB/D.IV/2624/VII/1998 tanggal 9 Juli 1998 perihal pemanfaatan lahan tidur). Dalam Surat Direksi tersebut telah diatur bahwa areal yang diperbolehkan untuk digarap oleh masyarakat sekitar kebun hanya boleh ditanami dengan tanaman palawija. Berdasarkan data dalam Tabel 1, terlihat bahwa hampir semua petani (92,20 persen) telah melanggar Surat Direksi tersebut, mereka lebih suka menanami lahan garapan mereka dengan tanaman nenas.
Kejadian selanjutnya, lahan tidur milik Perkebunan Tambaksari yang tengah digarap masyarakat, dikonversi menjadi tanaman kelapa sawit, situasi ini menjadi alat pemicu timbulnya konflik baru oleh oknum-oknum tertentu, yaitu salah satu LSM dan penggarap besar atau bandar nenas yang meminta pembebasan lahan garapan petani nenas yang sebenarnya milik Perkebunan Tambaksari, dengan cara memprovokasi masyarakat setempat.

Masyarakat sekitar perkebunan yang melakukan penggarapan lahan tidur dan menanaminya dengan nenas ada sekitar 60 persen, dan itu adalah masyarakat yang berasal dari golongan bawah yang benar-benar tidak memiliki lahan, atau yang memiliki lahan tetapi berada di bawah 0,5 ha. Alasan penggarap menanaminya dengan nenas karena tanaman nenas dapat memberikan penghidupan yang lebih baik daripada tanaman palawija terlihat dari nilai B/C > 1,42 (Pinondang Poltak Marganda,2006). Kondisi tersebut di atas, kemudian bertambah meruncing pada saat lahan tidur milik Perkebunan Tambaksari yang ditanami nenas oleh masyarakat dikonversi menjadi tanaman kelapa sawit oleh Perkebunan Tambaksari, ini menjadi pemicu konflik untuk timbul ke permukaan. Kejadian tersebut menimbulkan hubungan antara Perkebunan Tambaksari dengan masyarakat semakin memburuk. Di sini terlihat bahwa kepentingan dan tujuan kedua belah pihak berbeda. Karena adanya perbedaan kepentingan dan tujuan inilah maka timbul konflik. Hal ini sesuai dengan yang dikatakan oleh Ho-Won Jeong (2008): "Conflict represents the persistent and pervasive nature of inter-group and international competition among disparate interests and values that underlies power dynamics.” 


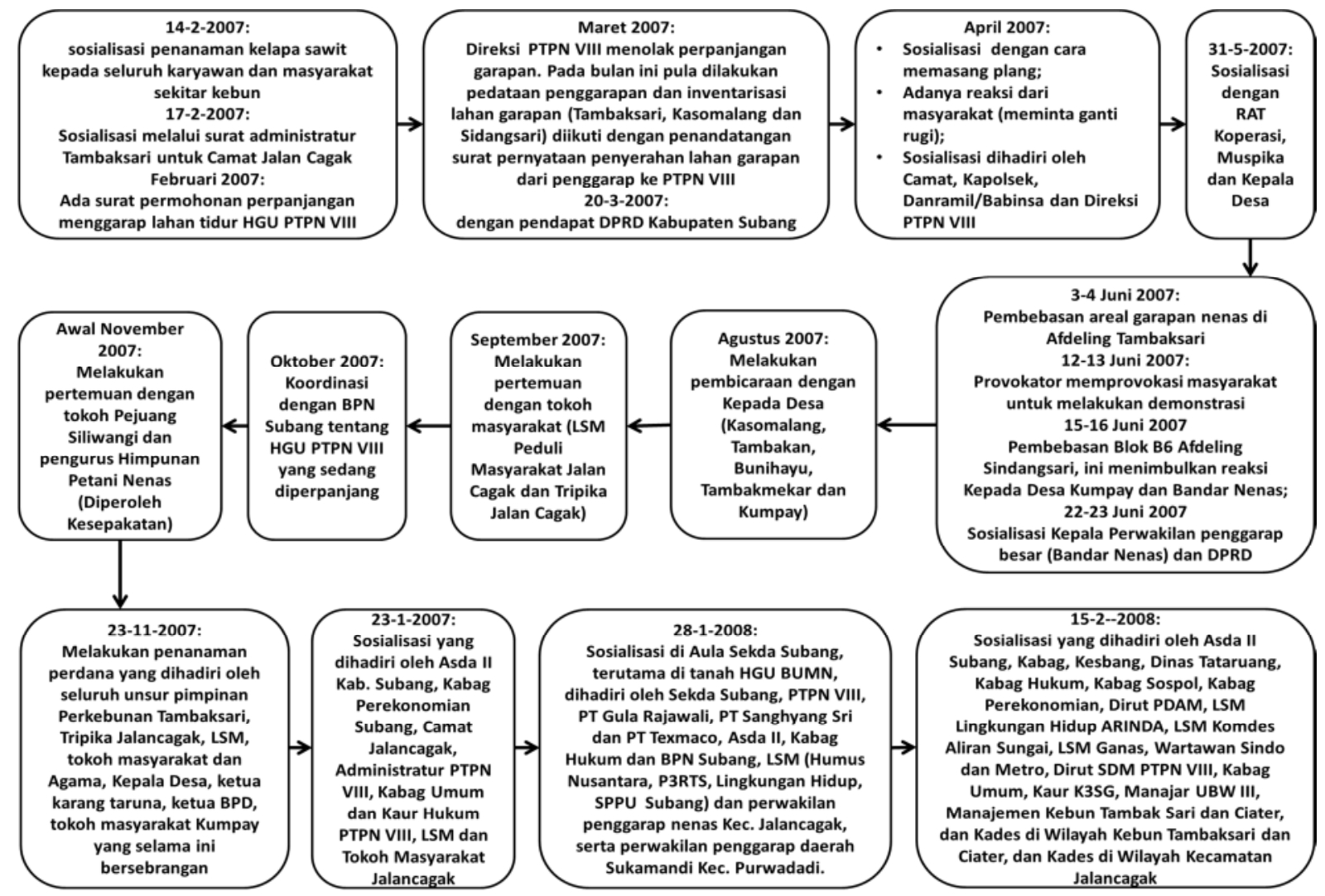

Gambar 2. Pemetaan Kronologis Penanganan Konflik Antara Masyarakat Sekitar dengan Perkebunan Tambaksari PTPN VIII

Berdasarkan hasil penelitian juga dapat diketahui kronologi kejadian yang menggambarkan mulai terjadinya konflik antara Perkebunan Tambaksari dengan masyarakat sekitar, sampai terjadinya mediasi dan pencapaian hasilnya (Gambar 2). Ini menunjukkan bahwa konflik antara perusahaan perkebunan dengan masyarakat sekitar, ternyata sudah terjadi sejak lama. Akan tetapi upaya penyelesaian konflik tersebut, walaupun sudah melibatkan banyak pihak, masih belum memberikan hasil yang memuaskan. Berdasarkan Gambar 2 tersebut, terlihat bahwa konflik antara Perkebunan Tambaksari dengan masyarakat sekitar dan penanganannya sudah melibatkan berbagai pihak terkait, seperti: pemerintah daerah, tokoh masyarakat, LSM, wakil dari masyarakat penggarap, Tripika, Ketua BPD, Kepala Desa, DPRD, wartawan Sindo dan Metro, dan lain-lain. Selain itu, konflik yang terjadi antara Perkebunan

Tambaksari dengan masyarakat sekitar sudah mengambil waktu yang cukup lama, dan belum tuntas terselesaikan. Ini menunjukkan bahwa pihak-pihak yang diajak untuk secara bersama-sama menyelesaikan konflik masih belum memahami pentingnya melakukan pemetaan konflik yang seharusnya dilakukan sejak awal. Usaha pihak Perkebunan Tambaksari untuk menangani konflik dan mensosialisasikan hasil kesepakatan antara pihak perkebunan dengan masyarakat telah dilakukan terus menerus, dengan melibatkan berbagai pihak terkait, dan ini telah telah dituliskan dalam "Laporan Penanganan Lahan Garapan Di Perkebunan Tambaksari”.

Konflik yang berkelanjutan tersebut juga menunjukkan bahwa belum terjadinya sinkronisasi antara keinginan perusahaan untuk tetap eksis dan berkinerja tinggi dengan keinginan masyarakat sekitar untuk dapat secara langsung merasakan manfaat dari keberadaan perusahaan perkebunan yang ada di wilayahnya. Hal ini menunjukkan pula bahwa dalam mencapai keinginan untuk tetap memiliki kinerja tinggi dan eksistensinya diakui oleh masyarakat karena dianggap bermanfaat bagi kesejahteraan mereka, perusahaan belum memanfaatkan pemetaan konflik sebagai alat untuk menyelesaikan konflik.

\section{KESIMPULAN}

Konflik terjadi karena kondisi rendahnya kesejahteraan masyarakat yang terdorong oleh 
adanya lahan tidur perusahaan perkebunan, belum selesainya perpanjangan HGU akibat panjangnya birokrasi, serta gencarnya provokasi dari bandar (pemilik modal) dan advocasi masyarakat dari LSM yang memanfaatkan celah-celah kondisi tersebut. Hal itu mengakibatkan konflik penyerobotan atas lahan perusahaan perkebunan oleh masyarakat sekitar, baik lahan tidur maupun lahan produktif. Konflik semakin meningkat karena adanya konversi lahan tidur yang ditanami nenas oleh masyarakat menjadi tanaman kelapa sawit oleh perusahaan perkebunan yang tidak disertai dengan musyawarah secara non formal, pendekatan partisipatif, kesepakatan kolektif dan ganti rugi. Ego kedua belah fihak tampak nyata dalam konflik ini, sehingga mengakibatkan berjalan berlarut-larut.

Walaupun penanganan konflik sudah berlangsung lama dan sudah melibatkan berbagai pihak terkait, seperti pemerintah daerah, tokoh masyarakat, LSM, wakil dari masyarakat penggarap, Tripika, Ketua BPD, Kepala Desa, DPRD, serta wartawan Sindo dan Metro sebagai perwakilan media publik, namun konflik masih saja terjadi hingga kini. Hal ini menegaskan bahwa pihak-pihak yang diajak untuk secara bersama-sama menyelesaikan konflik masih belum memahami pentingnya pemetaan konflik yang seharusnya dilakukan sejak awal. Oleh karena itu, direkomendasikan pentingnya mengintegrasikan metode penyelesaian konflik formal dan nonformal, sehingga mewadahi seluruh pihak yang terlibat dan terkait dalam menemukan solusi alternatif penyelesaian masalah.

\section{UCAPAN TERIMAKASIH}

Penulis mengucapkan terimakasih dan penghagaan yang setinggi-tingginya kepada Direksi PTPN VIII, Bapak Gunawan SH, Bapak Ir. Tatang Supriatna (Administratur Perkebunan Tambaksari), Bapak Ahmad Budi Santoso, SP (Sinder Pabrik Tambaksari), Bapak Asep Oman dan sekretaris administratur, serta staf dan seluruh karyawan bagian pabrik dan kebun Perkebunan Tambaksari, serta seluruh pihak yang tidak dapat penulis sebutkan satu persatu, yang telah memberikan ijin dan membantu penulis dalam melakukan penelitian.

\section{DAFTAR PUSTAKA}

Bartos, O. and Wehr, P. 2002. Using Conflict Theory. New York: Cambridge University Press.

Creswell, J. W. 1994. Research Design, Quantitative \& Qualitative Approaches. Sage Publication, Inc.

De Boers, A. and Hoa Pham. 2009. Brought to you by the Counselling Service. RMIT University.

Fisher, S. 2000. Working With Conflict: Skills and Strategies for Action. London/ New York: Zed Books.

Ho-Won Jeong. 2008. Understanding Conflict and Conflict Analysis. SAGE Publications Ltd; Los Angeles • London • New Delhi • Singapore

Muhamad Idrus. 2007. Metode Penelitian IlmuIlmu Sosial (Pendekatan Kualitatif dan Kauntitatif). UII Press; Jakarta.

Mukhsin Jamil. 2007. Mengelola Konflik Membangun Damai. WMC (Walisongo Mediation Centre); Semarang

Pinondang Poltak Marganda.2006. Analisis Ekonomi Kelembagaan Informal (Contract Farming) Dalam Usahatani Nenas Di Kabupaten Subang. Program Studi Ilmu Perencanaan Pembangunan Wilayah Dan Perdesaan Sekolah Pascasarjana Institut Pertanian Bogor.

Prahalad, CK. 2002. Managing and Implementing Change. www/Synergy Management Consultans Finland.

Robson, C. 2005. Real World Research. Blackwell Publishing; Australia.

Tosi, H.L; J. R. Rizzo and S. J. Carrol. 1990. Managing Organizational Dialog and Third Party Roles (2 ${ }^{\text {nd }}$ Edition). New York: Harper Collins Publishers.

Undang Fajar. 2006. Kemitraan Usaha Perkebunan: Perubahan Struktur yang Belum Lengkap. Journal: Forum Penelitian Agroekonomi. Volume 24 No. 1, Juli 2006:46-60. 